\title{
Foreign Direct Investment For Developing Financing: Teaching Market-Related Aspects Through Cases
}

Richard J. Hunter, Seton Hall University, USA

Héctor R. Lozada, Seton Hall University, USA

\begin{abstract}
This article presents two cases that have been used to supplement the teaching of how marketrelated aspects impact decisions, policies and tasks associated with attracting foreign direct investment into emerging markets and developing economies. The authors share their experiences in workshops and in the classroom and provide discussion strategies and teaching notes for each case.
\end{abstract}

Keywords: Transition Economies, Developing Countries, Case Studies

\section{INTRODUCTION AND CASE OBJECTIVES}

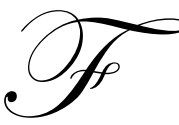

oreign direct investment (FDI) occurs with the purchase of the physical assets or a significant amount of the ownership (stock) of a company in another country to gain a measure of management control. According to the United States Department of Commerce, FDI inflows are counted from a 10 percent stock ownership in a company abroad. FDI involves a more direct and extensive form of participation or involvement of an enterprise in a foreign country. It represents investments in, or acquisitions of plants, equipment, or other assets. FDI has contributed greatly to the process of economic development and the general pattern of globalization in the past 40 years, increasing capital flows into countries with limited domestic financial sources and restricted opportunities to raise capital in world financial markets. Four groups of "industry globalization drivers"market, cost, government, and competition-represent the necessary conditions that determine the potential and need for competing with a global strategy (Porter 1986; Yip 2003).

FDI may be distinguished from straight portfolio investment (also called passive investment) that does not involve obtaining a degree of control in a company. Examples of traditional portfolio investment are the purchase of corporate debt securities, bonds, interest-bearing bank accounts, treasury bills, and notes. Portfolio investment has held a clearly secondary position in terms of both economic development and transition to traditional FDI activities.

More than 60,000 multinational companies with over 800,000 affiliates abroad are literally driving FDI flows. FDI worldwide increased to $\$ 1.2$ trillion in the year 2002, up from $\$ 1.3$ trillion in 2000. Developed or industrialized economies, led by the United States, received the largest share of FDI inflows, with $\$ 281$ billion, more than all developing countries combined, at $\$ 208$ billion. Developed nations, European Union nations, the United States, and Japan accounted for more than 70 percent of world inflows and 82 percent of outflows in 2000.

In this context, FDI has continued to expand greatly, after growing about 20 percent in the first half of the decade of the 1990's. FDI continued to grow at a rate of 40 percent in the period 1995-2000. FDI continues to grow faster than both world industrial production and international trade. ${ }^{1}$ Reflecting this growth, the top ten foreign

\footnotetext{
${ }^{1}$ United Nations Conference On Trade And Development, World Investment Report (2001/2002). See also www.UNCTAD.org (last visited Feb. 15, 2003) (presenting inflows, outflows, inward stocks, and outward stocks of FDI for 196 reporting economies in an interactive format).
} 
investment host countries, in rank order of attracting investment, include: the United States, the United Kingdom, France, Belgium and Luxembourg, Netherlands, Germany, Canada, Spain, Italy, and Sweden.

The major recipients of FDI in developing and transition countries have been China, Brazil, Bermuda, Czech Republic, Argentina, Mexico, Chile, Poland, the Republic of Korea, Thailand, and Venezuela. Hong Kong and Singapore continue to attract significant amounts of FDI. FDI inflows to developing nations in Asia hit a record $\$ 143$ billion in 2000 , with Hong Kong itself attracting $\$ 64$ billion. $^{2}$ FDI flows to China were $\$ 41$ billion. Elsewhere, FDI inflows to all of Africa accounted for only 1 percent of the world total in 2000, declining from about $\$ 10$ billion to slightly more than $\$ 9$ billion in 2000. FDI inflows into Latin America and the Caribbean also fell in 2000, by 22 percent, to $\$ 86$ billion. Privatization of state-owned assets or state-owned enterprises (SOEs) in Central and Eastern Europe ${ }^{3}$ continues to be a driving force behind FDI inflows into this region. ${ }^{4}$

The extent of economic development of a market determines the types of business and methods by which business can be carried out in a country. The shortage of goods and services is a key problem in less developed and developing countries. The most pressing need in these countries is to expand production. From a business standpoint, an increase in global competitive pressures has forced many firms to reevaluate their strategies and look for new markets in the developing world. Making strategic decisions about the developing world is made more complex by the fact that several developing countries grew considerably more rapidly in the 1990s than most of their counterparts. Countries like India, Argentina, and Poland, to name a few, classify as emerging markets (EMs) and represent major marketing opportunities. In a sense, it forces the developing world to reassess the way each country or region competes for foreign capital for investment. EMs are attractive because:

1. An identifiable target market has emerged as the early stages of economic development raise disposable income levels and the increasing reach of international media and MNEs influences product awareness and perception.

2. The Internet has made it possible for small and medium-sized MNEs to reach business customers in EMs that would not otherwise warrant the time and cost of establishing distributorships.

Marketing factors and the corporate desire for growth are major causes for the increase in foreign direct investment. Corporations need to seek wider market access in order to maintain and increase their sales. Different ownership levels of foreign investments are possible, ranging from wholly owned subsidiaries to joint ventures. Although many firms prefer full ownership in order to retain full control, such a posture is often not possible because of governmental regulations. Oftentimes, however, the focus is solely on the needs of the organization, with minimum regard to the needs of the host country where the investment is to be made. We propose that understanding the many issues confronting developing countries and/or countries with transition economies and their quest for foreign direct investment needs to be part of the total identification and selection of a target for investment.

We chose to create the fictional countries of Puerto Politza and Setonia to illustrate these issues without the confounding effects that the particular history of a specific nation (for example, Poland or Panama) might have presented. Instead, we combined different current events that occurred in several Eastern European countries

2 The information for the introductory section draws heavily from the primary data and analysis found in United Nations Conference on Trade and Development. See also www.UNCTAD.org (last visited Jan. 15, 2009); The World Bank, 2001 World Bank Atlas (2002). Updated figures for 2005-2009 may be accessed from this web-site as well.

3 For an "inside" appraisal of the region of Central and Eastern Europe, see Andrzej Kozminski, George S. Yip \& Anna Dempster, Evaluating the Central and Eastern European Opportunity: Eastern Promise, in Strategies For Central And Eastern Europe 1-32 (Andrzej Kozminski \& George S. Yip eds., 2000).

4 An effective global network can locate FDI activities to achieve the benefits of cost reduction and an increased competitive leverage. At the same time, this network must be configured to meet the key needs of local markets throughout the world. Professor Yip has created specific guidelines which summarize the key issues on this topic: differentiating between global centralization, local dispersion, and some combination in between; providing flexibility and safeguards against disruption; coordinating geographically dispersed activities; considering both strategic advantage and traditional comparative advantage in locating activities to maximize the competitive advantage of investments; and fostering research and development activities in globally strategic countries. 
(Puerto Politza) that are now considered emerging markets and several Latin American nations (Setonia) that are considered developing countries. Our focus is on the many geopolitical, economic, legal and cultural issues that may attract or scare away investors.

Our experiences with both cases have been positive. We have used the Puerto Politza case three times in graduate courses (one labeled "Doing Business in Central and Eastern Europe;" twice in "International Marketing") at our institution. Additionally, we have used this case successfully in four different seminars focusing on foreign direct investment since 2000. The seminars are co-sponsored by the Institute for International Business in the Stillman School of Business at Seton Hall University and UNITAR (the United Nations Institute for Training and Research) at the United Nations Headquarters in New York City and in Hiroshima, Japan. The feedback that we received corroborated that our initial intention of using a composite instead of the case of a particular nation facilitated the discussion of the many topics associated with foreign direct investment.

Although delegates from African and South American nations related to the predicaments of Puerto Politza, even though its context was Eastern European, they strongly encouraged us to develop a fact pattern that addressed the plights of developing countries. This is how Setonia came about. We used Setonia in conjunction with the Puerto Politza case in the Seton Hall-UNITAR seminar in August 2002. Once again, the feedback from the delegates was positive.

We hope that these cases provide you with opportunities to supplement a lecture on foreign direct investment and how an emerging market or developing country would have to market itself to potential venture capitalists. In addition to the cases, we provide teaching notes.

\section{PUERTO POLITZA SEEKS FOREIGN DIRECT INVESTMENT}

The tiny state of Puerto Politza (population 4.7 million; area, roughly the size of New Jersey) is located in the Sub-Carpathian Mountains. Puerto Politza was until 1989 a part of the larger Greater Ruthenian Federation, an independent Socialist Republic, which broke up when its only post-World War II leader, Leonid Piwowarty, was overthrown in a Christmas-Eve coup, witnessed by a worldwide CNN audience. Both Leonid and his wife, Zosia, were shot after a summary court martial.

Since that time, Puerto Politza has conducted an election for the Presidency. A national hero, Slawomir Skronek, imprisoned for nearly 20 years for "pro-democracy" activities, was elected President in 1990, running on the New Democratic Party (NDP) ticket. However, due to a worsening economic picture and endemic infighting among reformers and former allies and friends, Skronek was defeated for reelection in 1995 by Boris Piwowarty, son of the deceased former President. In addition, while initial elections to the Puerto Politzian Parliament resulted in a victory for the "New Democratic Party" (NDP) in 1993, the Left Social Democratic Party (LSDP), the successor to the Puerto Politzian United Workers Party (PPUWP), swept to victory in parliamentary elections, promising to restore workers to their former "respected positions" in society. Indicating that Puerto Politza has emerged as somewhat of a "normal country," the LSDP was subsequently defeated for another five-year term in 1998 by the NDP. They were, in turn, replaced by a coalition led by the NDP in 2003.

Prior to 1990, the country followed a monocentric system (control-rationing method (CRM) or system of central planning). The monocentric system is characterized by administrative price fixing by central authorities, isolation of domestic producers from foreign markets, excessive regulation of imports, soft budget constraints requiring constant revision of planning targets, monopolization and centralization of organizational rights. Puerto Politza began a series of gradualist economic reforms in 1991 and an aggressive privatization program in 1995, intending to privatize its 456 state-owned enterprises. Reforming of the Central Planning system involved attaining political stability and pluralism, implementing a program of economic reform with an evolution to a full market economy, development of a substantial private sector and a reduction of the state sector through a multi-track program of privatization, and creating and nurturing basic institutions of capitalism. To achieve stabilization and to liberalize the system, the independence of the Central Bank became critical. Additionally, the new government worked toward full convertibility of the currency, rapid elimination of shortages, and attacking hyperinflation. 
Puerto Politza specializes in mining (tin, glass) and small manufacturing and recently discovered 50 pure mountain springs from which it believes it can start both bottled water and beer industries. Many believe that due to its close proximity to the Ukraine, the "potato producing capital" of the world, Puerto Politza may be able to become the "spirits capital" of the world, specializing in cherry-flavored potato vodka!!!

A number of problems have persisted throughout the past 10 years. Unemployment is still very high (around 14\%) and the average wage in Puerto Politza is 795 glotzies (the "official" Puerto Politzian currency) per month (1 U.S. dollar $=1.5$ glotzies). Thus, no citizen of Puerto Politza had any excess glotzies with which to purchase privatization vouchers or shares in any privatized Puerto Politzian enterprise. In addition, the backwards Puerto Politzian legal and financial structures made it almost impossible to attract foreign capital. Currency issues were especially critical and detrimental, as was the fact that no "formal" tax code or joint venture law existed in Puerto Politza. Puerto Politzian foreign investment law required that the government retain a "golden share" in all investments for a period of 25 years. While foreign direct investment (FDI) was encouraged for certain Greenfield projects, they were generally undertaken on the basis of a BOT (Build-Operate-Transfer). It has come to the attention of the country leadership that the IMF may have some assistance programs, but they remain unaware about the specifics of what this would entail on their part.

In addition, while the position of workers was especially strong in the former Puerto Politza Socialist Republic, dominated by the Puerto Politzian United Workers' Party (PPUWP), the newly elected government has been surprisingly very hostile to workers' rights and has advertised that it was a goal of the "new" Puerto Politza to have an essentially "union free" environment. To make matters more complicated, the government still confronts a somewhat negative attitude on the part of the populace regarding foreign ownership.

Regarding the commercial infrastructure, Puerto Politza has lagged in the development of roads and highways, but not in the development of mass transportation systems and communications. There is a major highway that crosses the country from west to east. Another highway that will eventually cross the country from north to south has been plagued with misfortunes, including a landslide during the floods of 1996 . The government now estimates that the highway will be completed by 2009, 15 years behind schedule. The railroad system was privatized in 1996 in a process that involved months of demonstrations and protests on the part of the union workers. Nowadays, the system is effective and reliable. St. Stanislaosgrad, the capital city, has a metro system and two train stations: Stazzion Central, the largest of the two, is a block away from the Palazzio d'Leyes (the parliament); and Sta. Marthe in the northern part of the capital city, near the district that the government has reserved for industrial development. The government still owns a television station and a radio station. In 1995 it granted licenses for the development of two commercial TV stations and five radio stations. In 1998 cable television was introduced, with a basic service of 14 channels, one of them CNN International. Advertising agencies and market research firms are conspicuous in their absence.

Unfortunately, as of 2008, Puerto Politza still had been singularly unsuccessful in attracting significant amounts of FDI or in its privatization efforts. In the Spring of 2009, the Ministry of National Economy convened a conference of "experts" to address several issues critical to economic development. You are placed on a team of these "experts." The teams were presented with the questions in Table 1. You are asked to put together a brief report addressing these concerns. 
Table 1: Issues to be Addressed

\section{Geography}

1. Regarding Puerto Politza's geographic location, are there any problems that might be present?

Economy

2. Was the choice of the gradual option the only choice available? Was it the best choice?

3. After (hopefully) completing any existing privatization projects, how should the Privatization Ministry proceed? What specific actions should be undertaken?

4. Are there any serious "political or economic risks" apparent in Puerto Politza? Can they be overcome or at least minimized? How?

Currency

5. In the absence of glotzies, how could the Puerto Politzian government have assured citizen participation in the privatization process?

6. What currency issues are most important in the process of attracting FDI?

Legal Reform

7. What key elements of "legal reform" are necessary in the transformation process, especially in light of the objective of attracting FDI?

\section{Foreign Investment}

8. What about Puerto Politza might be attractive to potential foreign investors?

9. What marketing factors impact an investor's decision to invest in Puerto Politza?

10. What can the Puerto Politzian government do to "market" the country to foreign investors?

11. What can the Puerto Politzian government do to "market" the privatization reforms to workers and the populace?

12. How does a firm decide on an entry strategy for the Puerto Politzian market? How can the government use this knowledge in implementing the new policies for economic development?

13. Are there any ethical or social responsibility issues worth considering?

14. In attracting FDI, which are more attractive, BOOs or BOTs? Which are more problematic?

15. Should we explore with the IMF regarding their assistance programs?

16. Should the Puerto Politzian government permit private citizens to trade or sell their privatization vouchers?

17. What about the "golden share"?

Overall Assessment

18. Is Puerto Politza now behaving like a "normal" country? Why or why not?

\section{TEACHING NOTES}

\section{Case Discussion Strategy}

In our experience, the case works well when the class is divided in teams of 4 or 5 students each. Each team is then assigned a set of questions from Table 1. We have broken it down as follows:

\begin{tabular}{|c|c|}
\hline Team & Questions \\
\hline A & $1,2,3$ \\
\hline B & $4,5,8$ \\
\hline C & $6,7,17$ \\
\hline D & $10,11,12,13$ \\
\hline E & $9,15,17,18$ \\
\hline
\end{tabular}


We also asked that all teams address questions 14, 16, and 19.

\section{Suggested Answers and Discussion Points For Table 1}

\section{Geography}

1. Look at a map of the area of Central and Eastern Europe. Trace out the general outline of the "Iron Curtain." Discuss the "Yalta System" which involved the political and economic division of Europe. Stress especially the breakup of the former Soviet Union and the collapse of the Soviet Empire in the period 19891990. You may wish to assign students to study or "monitor" one of the nations in the region.

Economy

2. The radical or "shock therapy" approach involved the rapid and immediate move toward reaching economic goals. It was the embodiment of the plan adopted in Poland under Minister of Finance, Leszek Balcerowicz. Other nations (most notably China) adopted a more "gradual approach" to change the economy over a longer period of time. There is also an "intermediary approach" (called "rapid adjustment') that was practiced in stronger or weaker variants in some of the nations in the region. "Shock therapy" has been very difficult on citizens of the region who have been characterized as being on the brink of "social endurance."

3. The Privatization Program involves five steps:
a. $\quad$ Creation of a special agency or ministry to deal with privatization efforts;
b. $\quad$ Creation of a new business entity, termed a joint stock company, owned by the state;
c. Recognition that there will be a transition period during which the state-owned enterprise (SOE) begins to operate as a private enterprise;
d. The appointment of an independent financial adviser, perhaps drawn from the ranks of expatriate nationals;
e. Preparation of the legal system for privatization.

4. The full and free transfer of privatization vouchers is a necessary, final component of the process of privatization. It is one important component of a capitalist system and will lead to the creation of a capitalist market as citizens freely trade vouchers on the capital market.

\section{Currency}

5. Discuss the voucher system in which coupons or vouchers are sold or distributed at either no cost or at a nominal cost. These vouchers may be exchanged later either for stock in an individual privatized firm or for shares in "National Investment Funds," (NIFs) which are a bundling of various enterprises by sector. The voucher system is one important answer to the question: "How do you create capitalism in a nation where there is neither capital nor capitalists?" Some students may suggest the use of ESOPs (Employee Stock Ownership Plans/Programs).

6. Currency risks issues:
a. $\quad$ Floating rate; fixed rate currencies;
b. Blocked currencies.
c. Restrictions

Legal Reform

7. The following are important elements of legal reform necessary for successful privatization: 

a. $\quad$ Clearing of all expropriation claims;
b. $\quad$ Full discussion of reprivatization for former owners;
c. Recognition of private property rights through laws governing the acquisition and transfer of title; recording of mortgages; insurance; etc.;
d. Creation of a body of private contract law through a viable commercial code and the development of a transparent tax code.

\section{Foreign Investment and Marketing}

8. Factors that might attract investors include a relatively inexpensive and abundant labor force, good market location, access to natural resources or raw materials, good communication/transportation systems.

9. There are several issues that may be of varying degrees of relevance to potential foreign investors, depending on the industry that they represent. When compared with the tasks it faces at home, the firm attempting to establish a marketing organization in a foreign land will face a much higher degree of risk and uncertainty. This is a function of many factors, such as:

a. Differences in cultural environments. Perception of time, thought patterns, personal space, material possessions, family roles and relationships, personal achievement, competitiveness, individuality, social behavior (including communication mannerisms), and levels of education. It is no accident that managers usually prefer to move into environments that are perceived as more culturally close to their own.

b. Political uncertainty. The stability of governments, the possibility of armed conflict, the relationship between business and government (including an analysis of corruption and whether the business environment is plagued by mobsters). Also property seizure risks (Confiscation, expropriation, nationalization).

c. Import restrictions. Tariffs, import quotas, and other types of import restrictions are usually established to promote self-sufficiency and can be a huge roadblock. In other cases, governments may not impose restrictions that are commonly adhered to in the United States (e.g., access to intellectual property or technological innovation).

d. Exchange controls and ownership restrictions. Some nations establish limits on the amounts of earned and invested funds that can be withdrawn from it. Many nations have a requirement that nationals hold the majority ownership of a company operating there.

e. Economic conditions. Political upheaval and social change may affect the economic conditions of a country. Potential investors may want to perform in-depth analyses of a country's stage of economic development, the buying power of its populace, and the strength of its currency.

f. Marketing infrastructure. A thorough analysis of marketing channels: communication channels, distribution channels, selling channels. Marketers will require the support of several facilitators, particularly market research firms and advertising agencies if the intention is to penetrate that market. If the intention is to manufacture products so that they can be sold elsewhere, marketers will need to assess the current state-of-the-art of technology and physical plant, transportation modes, and warehousing facilities.

10. The whole notion of marketing gears around delivering value to specific customers better than competitors. In the case of the "marketing" of nations, governments may have to first establish what "value" it is that may be of interest to potential investors ("customers"). You may want to discuss how marketing organizations strive to uncover sources of competitive advantage and how this concept can be extended to the marketing of a nation for foreign direct investment. Once established, governments must then decide how to communicate the value to prospective investors. In order to better communicate the offer, the use of incentives may be considered (e.g., tax benefits or other concessions that the government is in a position to grant).

11. The government may have to engage in an educational campaign in which the process of privatization is explained. The government must also address the potential negative repercussions that these policies may have on the populace in the short-run, while enhancing the long-term benefits for the country as a whole. 
12. Discuss how firms face a major decision: to enter a foreign market or to pursue growth within a specific market. The type of strategy to employ will be a function of an analysis of market opportunities (see question 10), company capabilities (strengths), the degree of marketing involvement and commitment the company is willing to make, and the amount of risk that the company is able to tolerate. Three general approaches are available:

a. Make minimal investments of funds and resources by limiting the efforts to exporting.

b. Make large initial investments of resources and management effort to try to establish a long-term share of global markets (joint ventures, strategic alliances, direct ownership).

c. Take an incremental approach whereby the company starts with a low-risk mode of entry that requires the least financial and other resource commitment and gradually increase its commitment over time (licensing, franchising).

13. To discuss issues of ethics and social responsibility will require a discussion of economic conditions and cultural values. Cultural misunderstandings may oftentimes result in a perception of a behavior as unethical or socially irresponsible. A discussion of the meaning of self-referencing may be appropriate. Self-referencing is the process by which we make sense of the behavior of others through the use of own knowledge, attitudes, beliefs, and values. We learn these reference points from our own culture. Some issues that might be raised include the rights of workers during and after the transition, the development of healthcare facilities and schools, raising living standards (quality of life), and the use of violence for political/economic change.

14. Discussion of concession agreements through BOOs (Build-Operate-Own) or BOTs (Build-OperateTransfer). The BOT model might be more problematic in terms of attracting FDI because the foreign investor will not gain ownership at the end of the process.

15. Some of the possibilities to explore with the IMF include completing the highway system, developing human resources (education, training, retraining), assistance with legal reforms, assistance in stabilizing the currency.

16. The full and free transfer of privatization vouchers is a necessary, final component of the process of privatization. It is one important component of a capitalist system and will lead to the creation of a capitalist market as citizens freely trade vouchers on the capital market.

17. The "golden share" is the process by which the government maintains a controlling or majority interest in an industry (or perhaps even in a sector of the economy) even after privatization. This strategy is common for certain "strategic industries" related to national defense (railroads, ports, airports) or for "politically sensitive" sectors of the economy like transportation, health care, or communications. However, it should be pointed out that this strategy might be incompatible with eventual membership in the WTO which considers a "golden share" to be a non-tariff barrier!

\section{Overall Assessment}

18. What is it to be a normal country? Stress the element of economic reform that was required because of the virtual collapse of the former system and the progress that has been made in attaining macroeconomic success. On the political side, stress the holding of multiparty and free elections. Either you or your students can conduct a brief review of the economic progress and political "facts" of one of the nations of Central and Eastern Europe and report on the progress made. Some of the factors that might be used for assessing normalcy include: rule of law, free elections, good governance, corruption, human rights, and the development of physical, social, and commercial infrastructures. 


\section{Additional Remarks}

In the case of Puerto Politza, there are several suggestions that have been volunteered by student teams and that we like to accentuate:

1. Deregulation should be an integral part of the transition.

2. The country may want to explore regional cooperation agreements.

3. The tax code and investment law need to be standardized since this may attract foreign investors.

4. The government may want to adopt a policy of transparency as they move the country through a transition that may be rocky.

5. The government may consider opportunities to change the perception that the country is land-locked through a marketing campaign that emphasizes their geographical position the country is land-linked.

6. The World Bank and the UN system should be consulted for technical assistance.

\section{SETONIA}

The nation of Setonia is located in Central America in a wide, flat isthmus between the Atlantic and Pacific oceans. At its narrowest point in the south, it is just 19.5 miles across. Setonia has a population of just over 8.1 million people, occupying a landmass roughly the size of the state of Georgia. Its people have a literacy rate of approximately 50 percent and its workforce has the equivalent of a basic seventh grade education level. However, most are lacking in technical skills and computers are almost completely unavailable for general use.

Until 1973, Setonia was a part of the Trans-Galician Commonwealth (TGC). Its language, Setonese, is a combination of Portuguese, Spanish, English, rap, and native Indian. It was the last TGC colony located in the western hemisphere.

In 1973, Setonia achieved full independence from the TGC after an 11 year insurgency (1962-1973) that resulted in the death of more than 13,000 of its citizens and more than 3,500 TGC military personnel. During one of the major battles in Setoniaville, the nation's capitol, Archbishop Simon-Vega was killed on New Year's Day in 1972 by a TBC paramilitary force. He is now a national hero and has been proposed for sainthood by the Vatican chargee. The Church remains an important voice in Setonia society.

In 1983 and again in 1987 and 1993, troops from both Mexico and Canada had briefly "visited" Setonia in order to protect their diplomatic missions and their business interests in their former tin mine holdings that had been in operation for more than half a century but which had been nationalized, without compensation, by the Setonian government in 1982. As a result of these foreign interventions and a lack of buyers for its inefficiently made products, the mines were permanently closed in 1988 and are now filled with sea water.

After Setonia gained its independence from the TGC, a civilian government was formed to rule Setonia. It was overthrown after barely one week by a group of junior military officers. Today, Setonia is ruled by a military junta, led by General Oscar Lange, who seized sole, near dictatorial power in 1974. Lange's father had come to Setonia via Portugal and Germany in 1946-1947. A small opposition party, led by Fr. Jaime Vega, brother of the slain Archbishop, was organized in 1975 and has a few thousand adherents. It is illegal under Setonia law. Unlike his brother, Fr. Vega has been criticized by the Vatican for his perceived "Marxist leanings" and for sermons advocating a "true Marxist-Christian revolution in which all of Setonia's property would be owned by the poor."

National elections, already three times postponed $(1983,1993$, 1998), are tentatively scheduled for November of 2009. However, it is expected that the SSPRP (the Setonia Semi-Permanent Revolutionary Party) will emerge "victorious" in these elections and that Lange (now 87 or is it 92) will be inaugurated as Setonia's first "democratically elected" President in January of 2010. His son, Oscar Jr., is the nation's Prime Minister, and his daughter, Isabelita, is the Minister of Culture, Tourism, and the Economy.

On the economic front, Setonia's GDP stands at roughly $\$ 2,890$ per capita and 90 percent of the wealth is controlled by the top two to three percent of the population. Its growth rate was +1.8 percent for $2007-2008$, no 
growth is expected for 2009-2010. Inflation, which had been held in check in the decade of the 1990's, now stands at 20 percent. The currency unit, the tona, is currently "pegged" to the US dollar but rumors are now building that the tona will shortly be allowed to freely float. Many transactions are carried out by using US dollars, including the purchase of many capital goods like autos, and washers and dryers. It has been estimated that many of the "elite" in Setonia have foreign or offshore bank accounts.

Setonia has a large urban population. In fact, slightly more than half of its citizens $(4,275,000)$ live in the teeming and crowded capital, Setoniaville, a city roughly the size of Rochester, New York. The remaining half live in 250 or so small villages and towns situated throughout the countryside, nearly always along the coastal region. Outside the capital, the population is largely agrarian and almost illiterate. Until 1990, the only "cash crop" had been poppy seeds - which had been largely destroyed through the efforts of the Setonia government and the U. S. Department of Justice.

Setonia was hit by a major hurricane in 2006, causing extensive damage, loss of life (10,000 plus), and the virtual destruction of most of Setonia's infrastructure in telecommunications, health care, and roads. Unemployment currently stands at 19 percent and is rising. The foreign debt of Setonia is about $\$ 32$ billion (mostly caused by a series of blunders in attempting to create posh beach villas and luxury golf courses on its two coasts, an "abortive" second Panama Canal project, and the building of "Setonia Disney," a project which unfortunately could raise no private financial backers).

In 2005, Setonia found itself in "technical default" of its interest repayment obligation, but managed to secure a last-minute $\$ 3$ billion emergency stabilization loan from the IMF, underwritten by the United States. Setonia was able to continue its repayment obligations when it granted a "blanket concession" for ten years to the Miller Company to exclusively provide beer to Setonia's citizenry. As a result, Miller built five factories in Setonia in 2000-2005. These concessions will expire in 2010 and the ownership of these properties will revert to Setonia. Because there was no formal written agreement, Miller is contesting this situation on the basis of some "private assurances" given by the Setonia government.

Because of its poor education system and limited options, many Setonians, especially the sons and daughters of the political and military elite, went to the United States for their college or university education. Unfortunately, more than 70 percent have elected to remain in the United States once their studies were completed. ("Little Setonia" is a thriving urban community outside of Denver, Colorado, where more than 75,000 expatriates currently reside.)

Setonia also once had a thriving natural timber industry, providing balsa for most US-built surf boards. However, over-activity and cut-clearing depleted the crop to near zero production units by 1993 and resulted in an environmental disaster to the now chemically treated, polluted and fallow soil. As a result, more than 60 wood factories, previously employing more than 150,000 Setonians, stand idle and have gone into various stages of disrepair. The government unsuccessfully attempted to find private buyers for these factories and even advertised generous "timber concessions" to the private market in 1994. There were no significant takers - perhaps because the Setonian government insisted on perpetual majority government ownership of any operation and no provisions were found in Setonia corporation law, still undeveloped, providing for private ownership of the underlying real estate - further discouraging private investment. There is also a rather restrictive "foreign currency ownership law" passed in 1994 that prohibited the expatriation of profits from Setonia for a period of 20 years from any individual investment.

You should also know that in 2005, Setonia had applied for- but was not granted — a second but much larger \$60 million IMF stabilization loan for a combination of direct economic relief, restructuring of Setonia's banking system, and various soil and water development projects. The government did receive a much-needed temporary $\$ 8$ million in funding, but few if any of the funds found their way into the hands of the targeted project managers. (The Lange family, however, reportedly purchased six additional properties in Aruba, Jamaica, and South Beach, Florida.) The program was cancelled after only six months and the receipt of only $\$ 2.5$ billion in actual IMF funding. 
Despite earlier failures, since 1998, the Setonian government has embarked upon a reinvigorated program of once again trying to attract foreign investment. A new Foreign Investment Bureau (FIB), headed by Geraldo Lange (called Junior by the population), the son of the leader, was created to attract interest and private investment. Geraldo was educated at the Harvard Business School and was in fact a classmate of President George Bush. This strategy is extremely critical as another $\$ 3$ billion in interest is due in the fall of 2009 . Setonia policy-makers are very concerned about another impending debt crisis and are united in their view that a default on interest payments would be catastrophic.

Fr. Vega recently issued a statement that if he were in charge, outstanding loans would simply be "cancelled," and foreign banks and financial institutions could simply "go to hell!" You have been asked to serve on a National Commission designed to develop a strategy to attract foreign investment. Good luck!!!!

Table 2: Brief Chronology

\begin{tabular}{ll}
1962 & Setonia insurgency begins \\
1972 & Archbishop Simon-Vega murdered on New Year's Day \\
1973 & Independence granted by the TGC after an 11-year struggle \\
1974 & General Lange assumes power in a military coup \\
1975 & Opposition party founded by Fr. Jaime Vega, brother of slain archbishop \\
1982 & Setonia tin mines nationalized without compensation \\
$1983 / 1987$ & Foreign troops in Setonia to assure safety of investments \\
$1983 / 1993$ & National elections postponed \\
1988 & Tin mines permanently closed and flooded \\
1992 & Major hurricane hits Setonia \\
1993 & Timber factories reach O production \\
1994 & First timber concessions offered; no major takers present \\
1994 & Foreign currency repatriation law enacted \\
1995 & "Technical default" in debt repayment; \$3 billion bailout from the IMF \\
$1996 / 1998$ & Miller Company builds breweries in Setonia \\
1996 & IMF assistance package in the amount of \$8 billion received \\
1998 & FIB created \\
2002 & \$3 billion in interest payments due \\
2003 & National elections again postponed \\
2005 & IMF Loan application rejected \\
2010 & First "democratically" elected president scheduled to take office \\
2010 & Miller concessions scheduled to expire \\
\hline
\end{tabular}

\section{QUESTIONS FOR DISCUSSION}

1. What conclusions you have reached concerning Setonia?

2. How would you classify the economy of Setonia? Is it a developing, developed, transition, or lesserdeveloped country?

3. What are the specific characteristics of Setonia that led you to this conclusion?

4. Describe the role of nationalization as a tool of a nation's political philosophy. What message does nationalization send to international financial institutions? What are a nation's normal and usual obligations upon nationalization? Is there a different viewpoint expressed by some governments in the region where Setonia is located? How is this process reversed?

5. Is political pluralism a necessary precondition to economic reform? Should it be a precondition to the receipt of international assistance? What about the Mexican or Taiwanese model of reform? (Economic reform first; political reform only later!) 
6. Where does the GDP of Setonia place it in relation to other national economies? Why are such classifications important?

7. Is Setonia really suffering from a "foreign debt crisis"? Why or why not? What are some possible remedies?

8. How would you characterize the educational system in Setonia? What result has it brought? What are the long-range implications?

9. What are economic concessions? What are the two prevalent models? What are the effects of the choice of the type of concession?

10. What "political risks" are especially prevalent in Setonia?

11. What are currency control risks? Are there any present in Setonia?

12. What is a "pegged currency"? What is meant by the "dollarization" of an economy? What are the practical and policy implications of dollarization?

13. How might the IMF/World Bank be solicited to assist in the process of economic restructuring of Setonia? Are there any general "preconditions" to such assistance?

14. How are the "London Club" and the "Paris Club" implicated in this scenario?

15. How would you suggest the FIB to proceed?

16. What legal/property issues are implicated by this fact pattern?

17. What are the general prospects for Setonia? Are your conclusions generally relevant to such economies?

\section{TEACHING NOTES}

1. Let the participants/students discuss their overall impressions about the situation in Setonia. Make a list of the conclusions reached through this initial discussion and evaluation. See if the participants/students can relate the situation described in the case to any "real world" situations.

2. Discuss the characteristics of the various classifications of nations. Based upon the factual circumstances, it should be apparent that Setonia is a classic "developing nation."

3. What are the particular characteristics in Setonia that led you to this conclusion?

4. First, point out that nationalization is the taking over of an entire industry or economic activity (health care, transportation, mining, banking, etc.) by a government through the exercise of its legitimate powers. Expropriation is the taking of a specific asset by the government. Both are similar to the exercise of eminent domain power in the United States. Introduce the issue of privatization as the process of reversing nationalization. Be prepared to distinguish between political privatization (the Thatcher model, carried on because of a fundamental change in the philosophy of the governing power), and economic privatization (caused by the virtual collapse of the former command-and-control [monocentric or central planning] system, as was the case in Central and Eastern Europe in the wake of 1989).

There is a great body of law developed concerning nationalization. Nationalization generally cannot be targeted at foreign ownership only (that would be discriminatory), must be carried out for some "public purpose," and the obligations incumbent upon a government upon nationalization or expropriation are the payment of prompt, adequate and effective compensation under what is called the Chorzow factory 
principle. There is a very different view, especially prevalent in many Latin/South America nations, which rejects the obligation of full compensation and which permits a nation-state to pay far less than the traditional "fair market value." This view is expressed under the Calvo Doctrine. This doctrine is not accepted, for example, in the United States or most of the Western hemisphere.

As noted earlier, nationalization is often reversed through the process of privatization. If time permits, a brief discussion of the "preconditions" for privatization can take place. Include the following issues: preparation for privatization; clearing of former ownership claims; creation of private property law; and perhaps the creation of a special privatization commission, agency, or independent government corporation. The issue of privatization is much more relevant in the discussion of transition economies.

5. Discuss the various models for economic change. The Mexico-Taiwan-South Korea-China model involves "economic reform (democracy), first; political reform, later-if at all." The Russian model involved "political reform, first; economic reform, later! You should also discuss the choice made by Poland, called "Shock Therapy," which involved the simultaneous reform of both the economic and political systems. Which philosophy seems more taxing on the local population? Which is more "dangerous" to the incumbent political group? Which is more likely to assure broad social acceptance?

6. Discuss the classifications of economies based upon GDP. Point out that receipt of international aid is often contingent upon the classification of the applicant economy and that many World Bank/IMF grants have been reserved for nations with low GDPs. It might be appropriate to note that the IMF funds specific development projects; while the World Bank concentrates more on institutional approaches and fundamental organizational restructuring.

7. A foreign debt crisis arises when a debtor nation is unable to meet its interest obligations in a timely fashion - not to mention the inability to repay any principle amounts. There is a major debate as to the propriety of requiring a nation (ultimately to the disadvantage of the people) like Setonia to repay debt incurred for unwise or wasteful projects-especially those that personally benefited corrupt elites in society. The issue of "third world debt relief" would be an appropriate topic of discussion if time permits. Remedies involve debt forgiveness, interest payment reductions and delays, and further debt negotiations with members of either the "Paris Club" (public, nation-to-nation debt) or the "London Club," private institutional debt. The resolution of the debt crisis may also be assisted by intervention of the World Bank - but that might involve significant changes in the Setonia economy based upon World Bank criteria and the requirement of continued surveillance — as preconditions to assistance.

8. Discuss the effects of the "brain drain" on prospects in developing nations. The "brain drain" is a significant impediment to future prospects for sustaining economic and political reform. Have any of the participants/students personally witnessed the "brain drain" phenomenon?

9. Discuss the two prevalent models for economic concessions: BOOs [build-operate-own] and BOTs [buildoperate-transfer]. Point out that the $\mathrm{BOO}$ model has been much more effective in attracting foreign direct investment. Discuss what type of projects is especially attractive for economic concessions - namely, infrastructure improvements or those projects with high capital requirements that might prove difficult for a struggling or cash-strapped government to finance.

10. Discuss the issue of limiting repatriation of profits and how such a practice is a deterrent to attracting foreign direct investment. Discuss the legitimate interests in a nation to assure that foreign investors do not simply reap profits to the detriment of the host economy.

11. Discuss the existence of any "political risks" in Setonia. Permit the students to create a list of those obvious (religion, age of the President, succession issues, etc.) and state the impact of such risks on potential investment decisions. 
12. Provide a definition of a foreign currency that is "pegged" to the US dollar - that is, a currency whose value is officially tied/linked to the US dollar. Point out that when a currency is permitted to float, exports generally become more attractive (thus generating funds) but "locals" may see inflation destroy their own wealth. It is apparent that currency problems have already contributed to the marked increase in inflation in Setonia.

Discuss what can happen to the national currency when major transactions are carried out in a foreign currency, that is, become dollarized. Discuss how the national currency will loose all of its real value under these circumstances and will become worthless in any practical sense.

13. Discuss the preconditions that the World Bank might place on a nation like Setonia before any decision might be made to intervene. Setonia might be placed under the effective "stewardship" of the World Bank before any extensive help would be forthcoming.

14. As noted above, intensive "negotiations: may be required with London and Paris Club members. A listing of major Paris Club members include: Germany, France, Austria, the United States, Brazil, Canada, the U.K., Italy and Japan. London Club institutions include: Salomon Brothers, BFG Bank, Commerz Bank, Swiss Bank Corp, Lloyd's Bank, BNP, Standard Chartered Bank, Westdeutsche Landesbank, Societe Generale, Bank of America, and Dresdner Bank. Before referring to the actual listing, see if the participants/students can identify the names of states/institutions that comprise these lending states/institutions. What happens upon debt restructuring? Who pays for any "deficiencies"? How many of these institutions have been affected by the current global downturn????

15. Have the students create a list of the major activities of a group or a specially established institution charged with spurring or stimulating FDI. Point out that it is important that a special agency be created to deal with FDI issues - and such an institution must be staffed by "experts" who can assist in attracting real foreign capital.

16. Describe the necessity of creating and assuring private property/ownership rights, including the ability of foreign parties to own real estate and to have any ownership rights (deeds) recorded in an official government bureau. Although the question does not strictly involve the issue of private contract rights, the issue of creating a viable commercial code should be explored.

17. Having discussed the various issues presented in the case, the participants/students should be prepared to offer their assessment on general prospects for a developing nation like Setonia.

\section{AUTHOR BIOGRAPHIES}

Richard J. Hunter, Jr. is Professor of Legal Studies and Faculty Fellow of the Institute for International Business, Stillman School of Business, Seton Hall University. He has written extensively on Eastern and Central European business, politics, law, and economics, including over 30 articles on aspects of political and economic transformation in Poland, and the books From Autarchy to Market: Polish Economics and Politics, 1945-1995 (with Leo V. Ryan) and Poland: A Transitional Analysis (with Leo V. Ryan and Robert E. Shapiro). He is a frequent presenter at numerous international conferences and a contributor to the United Nations Institute for Training and Research (UNITAR) Workshops on "Foreign Direct Investment for Development Financing" in New York City and Hiroshima, Japan.

Héctor R. Lozada is Associate Professor of Marketing and Faculty Fellow of the Institute for International Business, Stillman School of Business, Seton Hall University. Dr. Lozada is the author or co-author of over 20 research articles on marketing, environmentalism, and international business. He is a frequent presenter at various international conferences and a contributor to the United Nations Institute for Training and Research (UNITAR) Workshops on "Foreign Direct Investment for Development Financing" in New York City and Hiroshima, Japan. 


\section{REFERENCES}

1. $\quad$ George S. Yip (2003), Total Global Strategy 9.

2. Michael E. Porter, Changing Patterns of International Competition, 28 Cal. Mgmt. Rev. 9 (1986).

3. The websites of the World Bank and UNCTAD.

\section{NOTES}


NOTES 